\title{
All Hands on Deck: The Process and Activities of Collaboration between Chiefs and Local Government Authorities in Ghana
}

\author{
Kwabena Boateng \\ Department of Social Sciences, Central University, Accra, Ghana \\ Email: sekyerehene2002@gmail.com \\ Stephen Afranie \\ Centre for Social Policy Studies, University of Ghana, Legon - Accra \\ Email: safranie@ug.edu.gh \\ DOI//http://dx.doi.org/10.4314/gjds.v17i1.5
}

\begin{abstract}
Local governance historically revolved around chiefs. However, colonialism witnessed the transfer of the powers and functions of chiefs to local government authorities. Current local government legislations failed to provide the needed formalised process of collaboration between the two actors resulting in conflict and tensions between them. This notwithstanding, chiefs have exhibited their preparedness to collaborate with developmental partners including local government authorities. The study examined the processes and activities that chiefs and local government authorities collaborated for the purpose of community development. Simple random and purposive sampling techniques were used to select forty-nine participants from New Juaben, Ghana. Multiple qualitative methods including participant observation, in-depth and key informant interviews were used to collect data. The study revealed that chiefs and local government authorities collaborated on an ad hoc basis in organising communal labour and sanitation, disaster management, revenue mobilisation and crime prevention. Though chiefs and local government authorities collaborated in diverse activities, the process of collaboration was not formalised. Chiefs are however needed in local governance to aid in the materialisation of the objectives of community development. The study recommends for the formalisation of the process of collaboration between the two actors to enable the former play active roles in local government.
\end{abstract}

Keywords: Collaboration, Local GovernmentAuthorities, Chiefs, Community Development 


\section{INTRODUCTION}

Chieftaincy and local government structures are very instrumental as far as sustainable development is concerned. Chiefs have historically been agents of development (Boateng, 2010; Boafo-Arthur, 2006), managing communal resources and ensuring their sustainability for current and future generations. With the cessation of inter-ethnic conflicts, chiefs have now turned their attention towards poverty alleviation, providing humanitarian services for underprivileged members within their territories (Owusu-Sarpong, 2003). Chiefs liaise with developmental partners to provide essential services in rural areas where state institutions are either non-existent or inefficient in providing them.

In Ghana, the indispensability of the chieftaincy institution, culminated in their conscription into the colonial administration (Brempong, 2007; Blanton, Mason \& Brain, 2001; Rathbone, 2000). Chiefs during this era constituted Native Authorities and were saddled with the mobilisation of revenue, maintenance of law and order, ensuring good sanitation and healthy practices in their communities (Brempong, 2007; Sharma, 2003; Rathbone, 2000). However, their involvement in this system antagonised their relationship with the African political intelligentsia. This class, conceived chiefs as collaborators of the imperial regime and an impediment to independence. Perceived as an undemocratic institution, the mission of the postindependence political elite was to remove all forms of colonial vestiges from state institutions and transform the chieftaincy institution in line with the wave of transformations in the colony (Brempong, 2007; Rathbone, 2000).

When the Provisional National Defence Council (PNDC) government was restructuring the local government system, the regime considered the direct involvement of chiefs as undemocratic and contrary to the ethos of the military regime (Ayee, 2007). Though the 1992 Constitution guaranteed the chieftaincy institution, it only tasked the president to consult chiefs in the appointment of the not more than 30\% members of the District Assembly (Republic of Ghana, 1992). Also, Legislative Instrument (LI) 1589, 1994 failed to incorporate chiefs in any of the sub-district structures of the local government system. Though the Local Government Act (Act 462) acknowledges the significance of chiefs in social mobilisation and in general socio-economic development, the above legislations on local government failed to specify the process of collaboration or makes it mandatory for local government authorities to collaborate with chiefs who are critical for the materialisation of the objectives of decentralisation. 
In the absence of any formalised process of collaboration, chiefs have demonstrated their preparedness to work with local government authorities to ensure sustained development in rural areas. Research on chieftaincy and local government structures have often devoted attention to the collaboration and the challenges of such collaboration (Arthur \& Dawda, 2015; Dawda \& Dapilah, 2013), institutional partnership between chiefs and local government structures (Agbenorku, 2010; Mahama, 2009) and legal dualism (Boateng, 2013). Literature on the process of collaboration between the two actors is scanty. Also, about $10 \%$ of the global population live in extreme poverty and reside in the rural areas (World Bank, 2018). The rural extreme poor constitute about $80 \%$ of the extreme poor globally (Castaneda, Doan, Newhouse, Nguyen, Uematsu \& Azevedo, 2018). Most of the poor reside in Sub Saharan Africa, plagued with ethnic and civil conflicts, characterised by corrupt and dysfunctional central government, chronic diseases and food insecurity. As a result, knowledge about the process of collaboration is not misplaced as it will inform developmental partners on channels to adopt in introducing inclusive development projects in rural areas.

The study therefore seeks to explore the process and nature of collaboration and the activities chiefs and local government authorities collaborate in. The paper has been structured as follows to achieve the above objectives: 'theoretical framework' section presents the theoretical perspective of the paper. The section on 'Methodology' presents an overview of the study area and research methods adopted in this study. The subsequent sections present the findings and discussions on the process and activities of collaboration and the conclusion and recommendations.

\section{THEORETICAL PERSPECTIVE OF THE STUDY}

"Mixed government" was adopted to analyze the process of collaboration and the activities of engagement between chiefs and local government authorities. Mixed government connotes the cooperative interaction between distinct and independent political structures (Sklar, 2003). In many countries in Africa such as Ghana and South Africa, what resembles Aristotle's mixed government model characterises the political landscape (Englebert, 2003; Sklar, 2003). Within this system, traditional political structures coexist with modern governance structures. The former occupies the second dimension within the pantheon of political leadership behind sovereign states. Chiefs in this system hold positions in accordance with customary laws and their functions regulated by law. They also derive their legitimacy and 
mandate from traditions and customs while legitimacy of officials of modern governmental structures is derived from constitutional provisions.

Currently, traditional structures have been incorporated into governance. Thus in Africa, precolonial institutions from the colonial era, have competed with modern structures of governments for the allegiance of the citizenry (Ekeh, 1975). The level of incorporation varies across the continent - higher in Anglophone nations in Southern Africa (Sklar, 2003). Through public meetings (dikgotla), chiefs in Botswana are able to influence policies before they become legal frameworks (Sklar, 2003; Sharma, 2003). Ministers are permitted to attend such meetings to discuss bills under consideration. Chiefs are expected to carry out instructions determined by the Minister; failure to undertake such instructions is tantamount to either suspension or deposition (Sharma, 2003).

In South Africa, the House of Traditional Leaders and the Council of Traditional Leaders have been established at the provincial and national levels to advise governments on matters that border on traditions and customs (Englebert, 2003; Sklar, 2003). Paramount chiefs in Lesotho or their representatives occupy twothirds of seats in the Senate (Sklar, 2003). In Nigeria, though previous constitutions (1979 and 1989) provided for establishment of State Councils of Chiefs with representation in Federal Council of State as well as traditional councils with advisory roles in local government structures, the current 1999 Constitution failed to make mention of chiefs and their councils (Sklar, 2003).

In Ghana, the 1992 Constitution permits the establishment of a National House of Chiefs and a Regional House of Chiefs for each administrative region of the country. These organisations are tasked to advise persons or constitutionally mandated bodies on matters relating to chieftaincy and resolve chieftaincy disputes. Though the constitution debars chiefs from partisan politics, qualified ones can be appointed on national commissions or authorities for them to contribute to national development. The President of the National House of Chiefs is a member of the Council of State, a constitutional body that counsels the president of the republic (Republic of Ghana, 1992). Thus in a nutshell, the theory denotes the existence of two separate and distinctive realms of political power, rooted in diametrically opposed sources of authority. This notwithstanding, chieftaincy is the bedrock of political order, reinforcing social order without thwarting the foundations of democratic governments (Sklar, 2003). However, these distinctive political institutions interact or collaboration at many institutional levels in the performance of their functions (Sklar, 2003). 


\section{METHODOLOGY}

\section{Study Area}

New Juaben in the Eastern Region of Ghana was the study area. New Juaben is located within the New Juaben South Municipal Assembly (NJSMA) and New Juaben North Municipal Assembly (NJNMA) with Koforidua and Effiduase as capitals respectfully. The later was curved out from the erstwhile New Juaben Municipal Assembly (NJMA) in 2017 with the promulgation of Legislative Instrument (L.I) 2302 of December 2017 and the Local Governance Act, 2016 (Act 936). The two Assemblies have a heterogeneous population dominated by Akans. Other ethnic groups in the municipalities include Ewe, Guan, Gurma and Mole Dagbani (GSS, 2014; GSS, 2013).

Traditionally, the people of New Juaben have a centralised political system. At the apex of the chieftaincy institution in the region is the Regional House of Chiefs composed of all the heads of the traditional areas in the region. The New Juaben Traditional Council (NJTC) is headed by Daasebre (Emeritus) Oti Boateng. Nine divisional chiefs and numerous sub chiefs under them assist the paramount chief to administer the traditional area.

\section{Data and Methods}

Based on the research questions, the qualitative research approach was adopted. Qualitative approach seeks to understand why social phenomenon or people act the way they do in naturalistic settings without any influence from the researcher (Patton, 2002; Marshall \& Rossman, 1999). In this study, phenomenology, a type of qualitative research was adopted to understand how chiefs and local government authorities collaborate and the activities of collaboration. This approach was adopted because it attempts to understand empirical issues from the perspectives of participants. Although qualitative studies involve smaller participants (Creswell, 2007), it is flexible, promoting learning as well as prolonged interaction between the researcher and the participants.

The study involved forty-nine participants, composed of two females and fortyseven males. The target population was predominately males hence the gender imbalance in the sample composition. Though efforts have been made to bridge the gap between men and women, the latter in Ghana are less represented in key decision making in comparison with their male counterparts (Adatuu \& Gyader, 2019) as women face a layer of constraints in their quest to participate in decision 
making (Quansah \& Essien, 2014). Participants were selected through simple random and purposive sampling techniques. Two participants were selected through simple random sampling in towns ${ }^{19}$ with more than two Assembly members. A container for each community was labeled with the names of elected Assembly members placed in them. Two names were randomly picked from each container after being thoroughly mixed. The purpose was to give each elected member equal chance of representation in the study.

Purposively, all divisional chiefs and sub-chiefs who deputised for them in their absence and principal local government officials namely Municipal Coordinating Director, Municipal Planning and Finance Officers with ten years working experiences and who have worked in the municipalities for at least two years were involved in the study. Six (6) key informants including the former Director of the Institute of Local Government Studies (ILGS), the Dean of Graduate Studies and Research (ILGS), Deputy Director for Centre of Indigenous Knowledge and Endogenous Development (CIKOD), the President of the Eastern Regional House of Chiefs (ERHC), Registrar of the ERHC and a lecturer with proficiency in chieftaincy and local government at the Business School of the University of Ghana, Legon were interviewed.

Data was collected through semi-structured interviews and participant observation. Semi-structured interview was adopted because it offered us the opportunity to ask questions not contained in the interview guide and also pick up on things said by the interviewees (Bryman, 2012). As part of the participant observation, the researchers were involved in some activities such as fixing of street lights in the Effiduase electoral area organised by the local government authorities and in some meetings the two actors organised. Interviews were tape recorded, transcribed and managed with NVivo 11 software. Themes identified included process of collaboration and activities of collaboration. Pseudonyms were used to conceal the identities of participants. Below is a table illustrating the number of participants, reasons for selection and sampling techniques adopted.

19 These communities where simple random was conducted included Koforidua, Effiduase, Jumapo, Oyoko and Asokore. 
Table 1: Category of participants and sampling techniques adopted

\begin{tabular}{|l|l|l|l|l|}
\hline Category & No. & $\begin{array}{l}\text { No. } \\
\text { Sampled }\end{array}$ & Sampling Technique & Reason for Selection \\
\hline $\begin{array}{l}\text { Chiefs (Krontihene, } \\
\text { Divisional and Sub- } \\
\text { chiefs) }\end{array}$ & 19 & 19 & Purposive Sampling & $\begin{array}{l}\text { Traditional leaders } \\
\text { who have historically } \\
\text { undertaken community } \\
\text { development programs for } \\
\text { their people. }\end{array}$ \\
\hline $\begin{array}{l}\text { Principal Local } \\
\text { Government } \\
\text { Officials }\end{array}$ & 8 & 4 & Purposive Sampling & $\begin{array}{l}\text { They are heavily involved } \\
\text { in the development of } \\
\text { Medium-Term development } \\
\text { plan for the Assemblies. }\end{array}$ \\
\hline Assembly members & 27 & 20 & $\begin{array}{l}\text { Purposive and Simple } \\
\text { Random Sampling }\end{array}$ & $\begin{array}{l}\text { They are liaison officers } \\
\text { between the Assembly and } \\
\text { the people. }\end{array}$ \\
\hline Key informants & 6 & 6 & Purposive Sampling & $\begin{array}{l}\text { Experts in the field of local } \\
\text { governance and chieftaincy. }\end{array}$ \\
\hline Total & $\mathbf{6 0}$ & $\mathbf{4 9}$ & & \\
\hline
\end{tabular}

Source: Authors' construct (2019)

\section{FINDINGS AND DISCUSSION}

\section{Process and Nature of Collaboration between Chiefs and Local Government Authorities}

In the study area, modern governmental structures co-exist with traditional political system, depicting an extraordinary illustration of mixed government. The political head of the administrative region is the Regional Minister, an appointee of the central government. The Regional Minister heads the Regional Coordinating Council (RCC), the highest local government structure in the administration of the region. Beneath the Regional Minister are the Chief Executives who oversee the daily administration of the Municipal Assemblies aided by a bureaucratic staff.

Chiefs and local government authorities in the study area collaborated in diverse ways. The fundamental ethos for collaboration was to facilitate development. Thus, the inability of government to carve out definite functions for chiefs to perform in local government structures has not deterred chiefs from collaborating with local government authorities and other developmental organisations. The collaboration between chiefs and local government authorities is pivoted on the notion by the citizens that the latter has contributions to make in the fight against poverty and deprivations (Asamoah, 2012). The preservation of traditional political institutions 
and its representatives from the colonial era to present, was informed by the above orientation.

From the data, the process of collaboration between the two actors of community development was informal. This is contrary to the formalised process of collaboration between chiefs and government officials in Botswana in which the former are able to summon government officials to answer question bordering on their portfolio (Ray, 2003; Sharma, 2003) as a way of seeking for accountability from central government (Ray, 2003). In the absence of a formalised collaborative process, chiefs and local government authorities collaborated on an ad hoc basis and at the discretion of the parties concerned. Such informal collaboration has been described as a cooperative relationship (Seini, 2006). This cooperative relationship was as a result of the perceived symbiotic roles that chiefs and local government authorities perform regarding community development. The indispensability of chiefs is not only due to the resources they control but also their roles in galvanising resources for community development (Boateng, Afrianie \& Amoah, 2016; Boateng, 2010). In the face of the weak planning and implementation process that characterise the local administration, the involvement of chiefs in local government structures will enhance effective resource mobilisation for community development.

In New Juaben, chiefs and local government authorities collaborate in planning towards National Sanitation Days (NSD), organising communal labour during traditional festive occasions like Akwasidae and Akwantukese. By virtue of the fact that sanitation plays a vital role in development, the government of Ghana through the Ministry of Local Government and Rural Development (MLGRD), instituted the National Sanitation Day on September 13, 2014 (Sanah, 2014). Held on every first Saturday of the month, the day was set aside for the organisation of a nationwide clean-up.

The Akwasidae is part of the Akan traditional calendar, celebrated to commemorate the deeds of the ancestors and cement the bond between the living and the dead. The Akwantukese is the festival of the chiefs and people of New Juaben, celebrated to commemorate their origin and migration from Juaben, part of the Asante Kingdom during the colonial era.

According to the chiefs, the objectives of the festival include mobilising the people to undertake self-help developmental projects, re-enforcing the peace and unity between New Juaben State and Ashanti, serving as cultural and tourist attraction among others. Prior to the organisation of the Akwantukese festival, developmental 
projects were earmarked. Funds mobilised through the festival were channeled into such predetermined projects. The Akwasidae and Akwantukese were not only for purification purposes, but also avenues for the two stakeholders to strategically plan projects for the community. A chief indicated:

We take advantage of the Akwasidae occasions to plan together with our Assembly Members. During these periods, we come together and discuss every sector of the community, be it education, peace and security, health, etc. The Assembly members have ideas about the medium and long term developmental plans of the Assembly. With their presence at such meetings, we're able to strategise and know the bottoms to press to get the desired projects for our communities (IDI 28).

The presence of Assembly members at traditionally sanctioned meetings was to facilitate in charting developmental programs. A day before the climax of the Akwasidae family heads, Assembly members and other opinion leaders met to discuss the progress and growth of the community. Community leaders at these meetings notify their superiors about the needs and concerns of their subjects. Although some times past, these public forums attracted large sections of the people, recent meetings recorded low participation as a result of social change brought by Christianity and western education (Nukunya, 2016) and occupational mobility. This notwithstanding, the co-existence of traditional and modern structures of government enables chiefs the opportunity to invite local government authorities to attend traditionally sanctioned meetings answer questions on issues that chiefs need expatiation on (Ray, 2003; Sharma, 2003).

\section{Activities Chiefs and Local Government Authorities Collaborated in}

This section examines the activities of collaboration between chiefs and local government authorities.

\section{Crime Prevention}

Ghana is relatively peaceful compared with its neighboring countries. However, there are reported cases of crime and violence that create a sense of insecurity. Agencies of social control have been constrained in their quest to provide security for citizens as the nation promote peaceful co-existence among its citizens. The uneven distribution of security institutions, lack of personnel and funds are some 
of the militating factors. As a result, chiefs have been involved in crime prevention as one of the major functions for the establishment of the political institution is the maintenance of law and order. The orientation about the magnanimity of the ancestors to sanction subjects, instilled a high sense of orderliness among people (Nukunya, 2016; Abotchie, 2006; Assimeng, 1999). Though Christianity and western education has weakened the primacy of traditional beliefs and practices, chiefs continue to rely on tradition and customs to prevent crimes in rural communities. A 45-year-old participant indicated:

Chiefs continue to use traditions and customs to minimise corruption and criminal activities in their communities. For instance, when one commits a crime, the person is brought before the chief's court for adjudication depending on the case. People are happier going to the chief's court than formal courts (KI 5).

The introduction of modern structures of governance witnessed the transfer of the policing functions of chiefs to institutions of the state such as the Ghana Police Service. Article 200 (3) of the 1992 Constitution states that 'the Police Service shall be equipped and maintained to perform its traditional role of maintaining law and order" (Republic of Ghana, 1992, p.133). Despite the reduction in the functions of chiefs, they continue to be instrumental in maintenance of law and order and thus collaborated with local government authorities and the Ghana Police Service in crime prevention. A participant indicated:

Crime prevention is basically the function of Municipal Security Council (MUSEC). This Council is made up of the Municipal Chief Executive who is the chairman, Coordinating Director (secretary) and the other security agencies. So we first and foremost plan our activities, choose flashpoints and with the involvement of chiefs, conduct public education. This is exactly what we did in the management of the Suhyen chieftaincy dispute (IDI 10).

Despite the functions chiefs perform regarding crime prevention, they are not members of MUSEC. Chiefs use traditional durbars to educate subjects on the need to be security conscious. The Municipal Assemblies provided vehicles and other logistic to the Police Service to protect life and property. Existing security lights are repaired periodically while communities which lack some are provided mostly by the Assembly. Some local government authorities also solicited assistance from 
organisations and philanthropists to provide security lights for their electoral areas.

Another area of collaboration was in the creation of community watchdog committees. In a meeting between the District Police Commander for Jumapo and members of the Jumapo-Suhyen Zonal Council, Assembly members were admonished to collaborate with chiefs in the establishment of watchdog committees to help fight crime. Consultative meetings were held among chiefs, Assembly members and personnel of the Police Service prior to the establishment of these committees. The committee is composed of the youth who periodically conducted night patrols in their communities.

Some Assembly members opined that the institutionalisation of these vigilante groups, led to crime reduction. In Ada, the Assembly member indicated that prior to the establishment of these groups, some unscrupulous individuals broke into houses and made away with items like television sets, computers and other personal belongings. Reported cases of stealing and gambling have been minimised. The operations of these groups are not without challenges. A major challenge is lack of motivation and logistics for volunteers. Although participants indicated that some chiefs periodically provided financial assistance, such funds were insufficient considering the hazardous nature of their work. An Assembly member whose electoral area lacked a watch-dog committee opined:

For now no! Because we have been thinking of how to motivate the volunteers. We discussed the issue with the chiefs and they gave their consent adding that we the Assembly Members should try and find something for the people who will be deployed. They did not show any form of financial commitment from their end, they threw it to the Assembly Members and it will not work because we are not paid (IDI 13).

\section{Tourism Development}

Ghana is bestowed with abundant natural and cultural resources mostly located in the rural areas. The main activities of tourists are therefore concentrated in rural areas administered by local government authorities in collaboration with chiefs. New Juaben is endowed with numerous physical, historical and cultural resources helpful for conventional tourism. The scenic landscapes and the multiple ethnic characteristics make the area a favorable destination for adventure-seeking and exploratory tourists. Notable tourist sites include the Kentenkiren Water Falls, 
Akwadum-Mpaem Forest, Akyekyeso Crocodile Sanctuary, Obuotabiri Mountains and Bird View at Srodai and the Koforidua Park.

The celebration of the annual Akwantukese festival attracted people from far and near to New Juaben. Chiefs collaborated with local government officials to re-enact the history of the indigenes through the celebration of festivals and other cultural activities. An Assembly member indicated:

Our culture is a big tourism attraction. If you want to promote tourism, then we have to promote our culture through the celebration of festivals. I believe that this will help us promote tourism. You know, the Assembly partners chiefs in the organisation and celebration of festivals (IDI 12).

Participants underscored the collaboration between chiefs, local government authorities during the annual Akwantukese festival. The planning committee for the festival was composed of representatives from the Traditional Council, officials of the Municipal Assemblies and other individuals of New Juaben ${ }^{20}$. Effective collaboration between the two stakeholders in the management of tourist sites was considered paramount in the development and sustenance of cultural and eco-tourism. The objective of such collaboration was to eliminate any form of misconceptions and strifes that may surround the management of tourists sites in the community. Community involvement in decision making fostered a conducive atmosphere necessary for tourism development. Such an initiative promoted communal ownership of tourist sites and mobilised community support in policy formulation and implementation process in the tourism sector.

\section{Budgeting and Revenue Mobilisation}

In Article 240 (2b) of the 1992 Constitution of Ghana, Parliament is mandated to promulgate laws that "enhances the capacity of local government authorities to plan, initiate, co-ordinate, manage and execute policies in respect of all matters affecting the people within their areas..." (Republic of Ghana, 1992, p. 150). In addition, the Local Government Act 462, institutes a composite budget. This budget is aimed at synthesising and harmonising expenditure and revenue estimations for programs and projects for all the departments in the District. The budget included annual development plans and programs of the departments and organisations under the District Assembly. The Assemblies are to submit such budgets to the

20 Similar collaborations between chiefs and local government authorities existed in the Sevelugu-Nanton District (Mahama, 2009). 
National Development Planning Commission (NDPC) through the Regional Coordinating Council (RCC) for approval (Republic of Ghana, 1993).

The budgeting process entails an engagement between the Assemblies and the communities through civil society facilitation. Meetings are held on quarterly basis on how plans in the budget have been implemented and also strategise for the upcoming periods. Through durbars, planning officials solicited views of community members, trade unions and civil society organisations for budget formulation and fee fixing. Once the fees are accepted, programs are outlined to mobilise revenue with assistance of chiefs who were informed before revenue collectors visited their communities. Chiefs utilise the gong gong to inform community members about the arrival of the revenue collectors. Local government authorities added that some chiefs publicly paid their taxes to motivate their subjects. In addition, whenever revenue collectors faced challenges in the discharge of their mandate, chiefs offered assistance. A Planning Officer added:

The chiefs help us to collect revenue. At times some recalcitrant people may want to cause trouble for the revenue collectors. The chiefs come in to calm tempers. They also educate community members on the essence of paying their taxes. Whenever they come in like that, it increases revenue base of the Assembly.

Another participant asserted:

When a chief speaks, his subjects listen. They respect their voices even more than the politicians. As a result, chiefs are called to add their voice when it comes to awareness creation on the essence of tax payment. When chiefs are actively involved in this endeavour, it increases revenue mobilised by the Assembly. (IDI, 12).

Officials at the NJSMA indicated that collaboration with chiefs increased revenue of the Assembly. In 2016 for instance, internally generated revenue increased from a budgeted Ghc 4,191,854.oo to Ghc 4,346,143.77. Chiefs complemented the efforts of revenue collectors and played advocacy roles in revenue mobilisation ${ }^{21}$.

21 Chiefs assisted revenue collectors in the Sissala East District of the Upper West Region of Ghana (Dawda \& Dapilah, 2013). The advocacy roles by chiefs in the Savelugu-Nanton District increased internally generated funds to about 23\% (Mahama, 2009). 


\section{Disaster Management}

From 2012, Koforidua and its environs have been battling with flooding and landslides (Bentil, 2019). Torrential rains have claimed lives, displaced families and destroyed millions of Cedis of properties (Bentil, 2019; Allotey, 2019; Neequaye, 2019). Affected communities included Koforidua-Zongo, Oyoko, Asokore, Pipeline, Effiduase and Highways. In Koforidua-Zongo for instance, about 300 households were affected by flooding (Bampoe, 2016). After the disaster, stakeholder deliberations between chiefs and peoples in the affected communities, National Disaster Management Organisation (NADMO) and the NJSMA resulted in dredging of silted drains and some rivers in the Municipality. The Assemblies in collaboration with NADMO distributed relief items such as food, blankets, mattresses among others. to the affected victims with assistance of the chiefs.

\section{Communal Labour and Sanitation}

Communal labour basically refers to activities that are undertaken by a collectivity, entrenches a sense of belongingness and solidarity among the social organisation. Traditionally, activities undertaken through communal labour include clearing a footpath leading to a stream, construction of infrastructure, harvesting and raising barns. These activities and others, difficult to undertake alone, were normally undertaken collaboratively. The conviction of the participants was that similar favours would be returned in equivalent proportions when others required it. Communal labour is primarily anchored on three key elements; mutual assistance, exchange of equal amount of work and no monetary payment for labour. This nonmonetary exchange of labour through collective undertaking was characteristic of peasant communities (Suehera, 2006).

In Ghana, community members come together to perform tasks that benefitted the collectivity. Chiefs are tasked to mobilise their subjects to undertake activities for the mutual interest of the collectivity. Refusal of members of the community to participate in communal labour without prior approval from the chief attracted sanctions. In New Juaben, chiefs and local government authorities collaborated in organising communal labour. Numerous communal labour sessions were organised during the National Sanitation Days, Akwasidae, Independence days, statutory holidays and other festive occasions. During the National Sanitation Days for instance, the Assemblies gave gloves, shovels, cutlasses and cash to facilitate the work. Also, Zoomlion Ghana Limited and other sanitation companies provided vehicles to convey rubbish to designated places. A local government authority added: 
The chiefs have always supported us. For instance, during National Sanitation Days, the chiefs whose area the exercise is being held do not only mobilise their subjects for us but they personally lead the youth and community to participate in the exercise. In most instances by the time we get to the community the chief and his people have already gathered waiting for us to join them. (IDI 10)

The presence of chiefs motivated the citizens to fully participate in activities being undertaken. With the National Sanitation Day, Officials of the Municipal Assemblies, served letters to the various electoral areas, chiefs, religious organisations and other recognised groups in the Municipalities. Religious organisations served as channels for disseminating information on communal labour and to mobilise support for the program. Public facilities like schools, markets, clinics, community centers, among others. were cleaned through communal labour. In Sissala East District (Dawda \& Dapilah, 2013) and in the Savelugu-Nanton District (Mahama, 2009) chiefs collaborated with local government authorities in the organisation of communal labour as part of health promotion exercises. The existence of a mixed government has enhanced the collaboration between chiefs and government officials dealing with health issues like HIV/AIDS (Ray, 2003).

\section{CHALLENGES AFFECTING THE ACTIVITIES OF COLLABORATION}

The collaboration between chiefs and local government authorities is not without challenges. Though local government authorities acknowledged that chiefs are instrumental in community development, they are not enjoined by any legal framework to collaborate with chiefs. Chiefs are incapacitated in their quest to insist on being formally involved in the administration of the Assembly. Participants opined that some chiefs in the good books of the incumbent government were at times nominated as members of the Assembly. Also, chieftaincy dispute and lack of political will inhibited the formalisation of the process of collaboration and integration of chiefs into the local government system. These factors buttress those of Ayee (2007) on the reasons accounting for the lack of representation of chiefs in local government system. A participant indicated:

There is the believe that when chiefs are made part of the Assembly, disputes within the chieftaincy institution will trickle into the affairs of the Assembly. Based on that, politicians are unwilling to take steps to make chiefs part of the Assembly. (IDI, 21) 
A chief remarked:

Politicians acknowledge our significance and some utilise our institution to get into political office. When they win power, they forget to take the need actions to formalise our integration into local government structures. They turn to see us as competitors and not as collaborators. So you see, they pay lip service regarding our integration into the local government system. (IDI, 29)

Despite the prospects that collaboration between local government authorities and community members have for tourism sustainability, some participants indicated little collaboration existed between stakeholders in managing tourist sites. Participants noted that tourist centers belong to the community. Despite the existence of several tourist sites and potential ones yet to be developed, the tourism industry is beset with several challenges like underdeveloped sites, lack of incentives for investors and low local patronage. The Municipal Planning Officer of NJSMA outlined plans being undertaken to boost the tourism sector in the Assembly namely developing infrastructure such as roads, hostels and extension of electricity to tourist sites. A participant remarked:

The Assembly and the Ghana Tourism Authority do not collaborate with us in the management of the tourist center here. The youth and Opinion leaders have complained severally but nothing seems to be changing. I do believe that chiefs and the community should be involved in the management of tourist centers (IDI 33).

Although chiefs and local government authorities collaborate with the police, the chiefs denounced instances where some unscrupulous police officers connived with criminals to perpetuate crime. Some of these security officials even failed to protect whistle blowers who rendered vital information for the arrest of criminals. This worrying situation lends credence to the bad nuts who have infiltrated the force with impunity and committed crimes that have tarnished the image of the institution (Sarpong, 2014; Nyarko, 2014).

Some chiefs postulated that reduction in their powers coupled with their noninvolvement in Assembly deliberations was a challenge that beset the collaboration in disaster management. Chiefs were incapacitated in enforcing legislation promulgated by the Assemblies and demolition of unauthorised structures on water ways which caused flooding across the municipalities. Participants attributed the cause of the disaster to human factors such as indiscriminate dumping of 
refuse in open drains, construction of unauthorised structures and the inability to enforce sanitation laws. The inability to enforce basic building and sanitation by-laws resulted in the springing up of numerous unauthorised structures on water ways, blocking its flow. For fear of losing electoral votes, politicians prevented the Assembly from conducting demolition exercises. At times, politicians came in to plead with the Assembly to spare their supporters and family relations who violated environmental by-laws. This confirmed reports that the natural disaster was humanly made (Dagyenga, 2016; Nyabor, 2016). A participant indicated:

I must indicate that the flooding was humanly caused. Go to the affected areas and see how people have built close to water bodies. For some structures, they've directed their sewage directly into these water bodies polluting it. People have blocked water ways and have built on them. So when it rains, the structures prevent the other tributaries from joining it. People have built up to the mountains, and others have farmed on it. After the recent rains, the mountains gave up the water it absorbed resulting in the landslide (IDI 26).

Challenges that beset the organisation of communal labour include lack of accountability and transparency regarding the distribution of incentives, lack of logistics and funds. Some chiefs and local government authorities accused the Assemblies for not being transparent in the distribution of logistics that the government and partner institutions provided for communal labour. A chief remarked:

During one National Sanitation Day, the then Local Government Minister brought numerous dustbins, shovels, gloves, pick axes, boots to help the exercise. These items were dumped at the Municipal Assembly and were never shared to the communities. With just eight communities in New Juaben Traditional Area, no chief together with their people got any item to use to conduct the clean-up exercise. Do you expect the people to clean with their hands? The youth won't work without incentives (IDI 2).

There were occasions that incentives the Assemblies provided were insufficient considering the numerous communities under them. Some Assembly members also cited financial constraints as another challenge mitigating against the success of the national sanitation day and the organisation of communal labour in general. Funds 
from the Assembly for communal labour and the sanitation days were woefully inadequate considering the population in each electoral area. Since chiefs have been economically decapitated (Boafo-Arthur, 2006; Brempong, 2007; Rathbone, 200o), they are unable to support Assembly members financially during the sanitation days. Assembly members after these events, incurred debts which were never reimbursed by the Municipal Assemblies. An Assembly member indicated:

At first, the Assembly during every Akwasidea, used to give us about GHC 50.00 to undertake communal labour. But you know, looking at the economic situation in the country and the number of people who may attend this activity, the money is too small. Imagine if about twenty people turn up for communal labour and you want to buy kenkey for them, how much is a ball of Kenkey? Sometimes we spend huge amounts of money because the boys who come demand for water and food which you have to provide. So at times we have to find money to organise these activities. These funds too do not come frequently at times (IDI 3).

\section{CONCLUSION AND RECOMMENDATION}

Chieftaincy is very instrumental in local government and the attainment of the sustainable developmental goals. Despite their indispensability in the materialisation of the objectives of decentralisation, there is no formalised process of collaboration between chiefs and local government authorities. In the absence of the formalised collaborative process, this paper examined the informal processes of collaboration and the activities the two actors collaborate in within the theoretical framework of mixed government.

The study revealed that in the absence of formalised process of collaboration, chiefs and local government authorities collaborate on ad hoc basis. The perceived symbiotic roles of the two stakeholders as agents of community development, was a relaying incentive for them to collaborate. The processes of collaboration are initiated by both sides depending on particular activity at hand. For example, while local government authorities initiate a process for chiefs to collaborate with them to organise National Sanitation Days, chiefs initiate collaborative process for communal labour during festive occasions like Akwasidae and Akwantukese. These traditional occasions are not only purification periods for cementing the bond between the living and the ancestors but serve as an opportunity for stakeholders to fashion developmental path for the traditional area. 
Chiefs and local government authorities also collaborate in crime prevention, tourism development, communal labour and sanitation, disaster management, and revenue mobilisation. Challenges affecting the activities of collaboration also included lack of transparency regarding items for communal labour, lack of incentives, non-availability of alternative sources of livelihoods among others. Chieftaincy dispute and lack of political will on the part of government officials were the challenges that beset the formal integration of chiefs in local government structures. There is the need to recognise and respect the legal and political dualism that exist in the political landscape that fosters the co-existence of chieftaincy and modern structures of government. Chiefs are needed by the state to be actively involved in local government. The study recommends the formalisation of the process of collaboration between chiefs and local government authorities to enable the former to play active roles in local government and development.

\section{REFERENCES}

Abotchie, C. (2006). Has the position of the chief become anachronistic in contemporary Ghanaian politics? In I. K. Odotei \& A. K. Awedoba (Eds.), Chieftaincy in Ghana: culture, governance and development (pp. 169-191). SubSaharan Publishers. ISBN 978-9988-550-74-2.

Adatuu, R. \& Gyader, G. (2019). Contributions of Non-Governmental Organisations to Women's Participation in Local Governance in the Tamale Metropolis of Ghana. Ghana Journal of Development Studies, 16(2), 70-90.

Agbenorku, J. (2010). Partnership modalities between metropolitan, municipal, district assemblies and traditional authorities. Journal of Local Government Studies, 2(1), 1-21. ISBN: 2026-5840.

Allotey, G. A. (2019). Koforidua floods: 7-year-old dead after 2 hours of downpour. Retrieved from: https://citinewsroom.com/2019/o2/26/koforidua-floods-7year-old-dead-after-2-hour-downpour/

Arthur, D. D. \& Dawda, D. T. (2015). Promoting rural development through chieftaincy institutions and district assemblies: Evidence from Sissala East District, Upper West Region of Ghana. Ghana Journal of Development Studies, 12(1\&2), 165-177. http://dx.doi.org/10.4314/gjdsv13i1\&2.10.

Asamoah, K. (2012). A Qualitative study of chieftaincy and local government in Ghana. Journal of African Studies and Development 4(3), 90-95. http:// doi:10.5897/JASD11.089. 
Assimeng, M. (1999). Social structure of Ghana. Accra: Ghana Publishing Corporation. ISBN 9964-1-0421-9.

Ayee, J. R. A (2007, July). Traditional leadership and local governance in Africa: The Ghanaian experience. Paper presented at the Fourth National Annual Local Government Conference, Southern Sun - Elangeni, Durban.

Bampoe, D. (2016). Koforidua flooded [Photos]. Retrieved from: https:// dailyguidenetwork.com/koforidua-flooded-photos/

Bentil, N. L. (2019). Rain causes floods in Koforidua.

Retrieved from: https://www.graphic.com.gh/news/general-news/ghananews-raincauses-floods-in-koforidua.html.

Blanton, R., Mason, D. T. \& Brain, A. (2001). Colonial style and post-colonial ethnic conflict in Africa. Journal of Peace Research, 38(4), 473-489.

Boafo-Arthur, K. (2006). Chieftaincy in Ghana: Challenges and prospects in the $21^{\text {st }}$ century. In I. K. Odotei, and A.K. Awedoba (Eds.), Chieftaincy in Ghana: Culture, Governance and Development (pp. 145-168). Sub-Saharan Publishers. ISBN 9789988-550-74-2.

Boateng, K., Afranie, S. \& Amoah, S. K. (2016). Social mobilisation in the midst of social change: The Case of traditional authorities in Ghana. Journal of Educational and Social Research, 6(2), 103-112.

Boateng, K. (2010). Chiefs as agents of development: A study of chieftaincy and community development in the Asante Juaben Traditional Area. (Unpublished MPhil thesis), Department of Sociology, University of Ghana, Legon.

Boateng, P. (2013). Dualism in local governance: The Case of chieftaincy and local government in small communities of Akyem Abuakwa State of Ghana. (Unpublished Doctoral dissertation), Department of Sociology, University of Ghana, Legon, Accra.

Brempong, A. (2007). Transformation in traditional rule in Ghana, 1951-1996. Sedeco Publishing Limited. ISBN 9988-8300-7-6.

Bryman, A. (2012). Social research methods ( $4^{\text {th }}$ Ed). Oxford University Press Inc. ISBN 978-0-19-958005-3.

Castaneda, R. A., Doan, D. D. T., Newhouse, D. L., Nguyen, M. C., Uematsu, H. \& Azevedo, J. P. W. D. (2018). A new profile of the global poor. World Development, 101(1), 250-267.

Creswell, J. W. (2007). Qualitative Enquiry and Research Design: Choosing Among Five Traditions ( $2^{\text {nd }}$ Ed.). London: SAGE Publications. ISBN: 978-1-4129-1606-6 
Dagyenga, M. (2016). NADMO distributes relief items to K'dua flood victims. Retrieved from http://www.graphic.com.gh/news/general-news/nadmodistributes-relief-items-to-k-dua-flood-victims.html.

Dawda, T. D. \& Dapilah, F. (2013). Challenges of the collaboration between formal local government actors and the chieftaincy institution in Ghana: Lessons from the Sissala East District of the Upper West Region of Ghana. International Journal of Humanities and Social Science, 3(12), 238-246.

Ekeh, P. (1975). Colonialism and the two publics in Africa: A Theoretical statement. Comparative Studies in Society and History, 17(1), 91-112.

Englebert, P. (2003). Resurgent indigenous structures and the reconfiguration of power in Africa. In O. Vaughan (Ed.) Indigenous Political structures and Governance in Africa (pp. 26-59). Oluseyi Press. ISBN 978-8059-06-6.

Ghana Statistical Service. (2014). Population and housing census. Ghana Statistical Service.

Ghana Statistical Service. (2013). Population and housing census. Ghana Statistical Service.

Mahama, C. (2009). Local economic development and local government in Ghana: Navigating a viable path to reform. Journal of Local Government Studies, 1(1), 29-54. ISSN 2026-5840.

Marshall, C., \& Rossman, G. B. (1999). Designing qualitative research (3rd ed.). Sage. ISBN 0-7619-1339-4.

Neequaye, Y. (2019). 2-hr downpour floods parts of Koforidua; properties destroyed. Retrieved from: https://3news.com/2-hr-downpur-floods-parts-of-koforiduaproperties-destrpoyed/

Nukunya, G. K. (2016). Tradition and change in Ghana. Accra: Woeli Publishing Services. ISBN 978-9964-3-0293-2.

Nyabor, J. (2016). Floods submerge Koforidua again [Photos]. Retrieved from http:// citifmonline.com/2016/10/o3/floods-submerge-koforidua-again-photos/.

Nyarko, A. (2014, March 5). Two Policemen busted for robbing a businessman. The Ghanaian Times, pp. 4.

Owusu-Sarpong, C. (2003). Setting the Ghanaian context of rural local government: Traditional authority values. In D. I. Ray \& P. S. Reddy (Eds.), Grassroots chiefs in Africa and the Afro-Caribbean Governance (pp. 31-67). Calgary: University of Calgary Press. ISBN 978-1-55238-565-4. 
Patton, M. Q. (2002). Qualitative evaluation and research methods (3rd ed.). Sage Publications, Inc. ISBN 978-0-7619-1971-1.

Quansah, J. Y. D. \& Essien, D. (2014). Women participation in the local governance: A case of Tamale Municipality in the Northern Region of Ghana International Journal of Social Science and Humanities Research, 2(3), 216-224. ISSN 2348-3164.

Rathbone, R. (2000). Nkrumah and the Chiefs: The politics of chieftaincy in Ghana 19516o. Ohio University Press. ISBN o-85255-770-1.

Ray, D. I. (2003). Rural Local Governance and traditional Leadership in Africa and Afro-Caribbean: Policy and Research implications from Africa to the Americas and Australasia. In D. I. Ray, \& P. S. Reddy (Eds.), Grassroots Chiefs in Africa and the Afro-Caribbean Governance (pp. 1-30). University of Calgary Press.

Republic of Ghana. (1992). Constitution of the Fourth Republic of Ghana. Assembly Press.

Republic of Ghana. (1993). Local government Law (Act 462). Ghana Publishing Corporation.

Sanah, A. K. (Wednesday $17^{\text {th }}$ December 2014). How National Sanitation Day started. Ghana News Agency. Retrieved from http://www.ghananewsagency.org/ features/how-national-sanitation-day-started-83675

Sarpong, O. A. (2014, March 18). Police Administration to clamp down on miscreants, criminals in the service. The Ghanaian Times, pp.10.

Seini, W. A. (2006). The Role of Traditional Authorities in Rural Development. In I. K. Odotei \& A. K. Awedoba (Eds.), Chieftaincy in Ghana: Culture, Governance and Development (pp. 547-564). Sub-Saharan Publishers. ISBN 978-9988-550-74-2.

Sharma, K. C. (2003). Traditional leadership and rural local government in Botswana. In D. I. Ray, and P. S. Reddy (Eds.), Grassroots Chiefs in Africa and the AfroCaribbean Governance (pp. 249-262). University of Calgary Press. ISBN 978-155238-565-4.

Sklar, R. L. (2003). The premise of mixed government in African Political Studies. In O. Vaughan (Ed.), Indigenous Political structures and Governance in Africa (pp. 3-25). Oluseyi Press Ltd. ISBN 978-8059-06-6.

Suehara, T. (2006). Labour Exchange Systems in Japan and DR Congo: Similarities and Differences. African Studies Quarterly, 9(1-2) 55-65. http://asq.africa.ufl. edu/files/Suehara-VolgIssue12.pdf

World Bank. (2018). Poverty and equity database. In The World Bank. Washington, DC. Retrieved from http://povertydata.worldbank.org/poverty 